\title{
The Study of Revenge Tragedies and Their Roots
}

\author{
Rajabali Askarzadeh Torghabeh * \\ Department of English Language and Literature Faculty of Letters and Humanities, Ferdowsi University of Mashhad, Iran \\ Corresponding Author: Rajabali Askarzadeh Torghabeh, E-mail: asgar@um.ac.ir
}

\section{ARTICLE INFO}

Article history

Received: February 27, 2018

Accepted: April 20, 2018

Published: July 01, 2018

Volume: 7 Issue: 4

Advance access: May 2018

Conflicts of interest: None

Funding: None

\begin{abstract}
Tragedy has its roots in man's life. Tragedies appeared all around the world in the stories of all nations. In western drama, it is written that tragedy first appeared in the literature of ancient Greek drama and later in Roman drama. This literary genre later moved into the sixteenth century and Elizabethan period that was called the golden age of drama. In this period, we can clearly see that this literary genre is divided into different kinds. This genre is later moved into seventeenth century. The writer of the article has benefited from a historical approach to study tragedy, tragedy writers and its different kinds in the Sixteenth and Seventeenth centuries. The author has also presented the chief features and characteristics of tragedies. The novelty of the article is the study of Spanish tragedy and its influences on revenge tragedies written by Shakespeare and other tragedy writers. Throughout the article, the author has also included some of the most important dramatists and tragedy writers of these periods including Thomas Kyd, William Shakespeare, John Marston, George Chapman, Tourneur and John Webster.
\end{abstract}

Key words: Tragedy, RevengePlays, Sixteenth and Seventeenth Centuries, Spanish Tragedy

\section{INTRODUCTION}

\section{Background and Definition of Tragedy}

A revenge play is also a revenge tragedy. This kind of tragedy "is brought about by the pursuit and accomplishment of revenge. It is blood asking for blood. The revenge tragedy was very popular during the Elizabethan and Jacobean periods, and it owed its popularity largely to the influence of Seneca the ancient Roman dramatist" (www.Scribd.com).

In his definition of tragedy, Abrams (1999) writes that "Senecan tragedy was written to be recited rather than acted; but to the English playwrights, who thought that these tragedies had been intended for the stage, they provided the model for an organized five-act play with a complex plot and elaborately formal style of dialogue" (p.323). He then adds that:

Senecan drama in the Elizabethan Age had two main lines of development. One of these consisted of academic tragedies written in close imitation of the Senecan model, including the use of a chorus, and usually constructed according to the rules of the Three Unities, which had been elaborated by Italian critics of the sixteenth century; the earlier English example was Thomas Sackville and Thomas Nortons Gorboduc (1562). (p.323)

Abrams (1999) continues and explains that the other and much more important development was written for the popular stage, and is called the revenge tragedy, or (in its most sensational form) the tragedy of blood. This type of play derived from Seneca's favorite materials of murder, revenge, ghosts, mutilation and carnage, but while Seneca had relegated such matters to long reports of offstage actions by messengers, the Elizabethan writers usually represented them onstage to satisfy the appetite of the contemporary audience for violence and horror (p.323).

Perhaps Thomas Kyd's Spanish Tragedy (1586) was the first revenge play in its kind and as Abrams says, "established this popular form, its subject is a murder and the quest for vengeance, and it includes a ghost, insanity, suicide, a play-within-a-play, sensational incidents, and a gruesomely bloody ending" (p.323). Following Kyd's revenge tragedy, there was a spurt of revenge plays, and "it was during James's reign that many of the most famous tragedies and comedies in English were written and first performed" (Widdowson, 2004, p.9). Abrams (1999) names these famous playwrights and writes: "Christopher Marlowe's The Jew of Malta (1592) and Shakespeare's Titus Andronicus (1590) are in this mode; and from this lively but unlikely prototype came one of the greatest of tragedies, Hamlet, as well as John Webster's fine horror plays of 1612-13 The Duchess of Malfi and The White Devil" (p. 323).

Other playwrights who continued writing of revenge tragedies are; John Marston (1575-1634) with his revenge tragedies of Antonio's Revenge and Antonio and Mellida. George Chapman with his powerful revenge play The Revenge of Bussy D'Ambois. The other playwright that should be named

Published by Australian International Academic Centre PTY.LTD. 
here is Tourneur, whose masterpieces of revenge tragedies are The revenger's Tragedy (1607) and The Atheist's Tragedy (1611).

\section{Major Characteristics of Tragedies}

The main features and characteristics of revenge tragedies are as follows: "a) Some murder is committed and the ghost of the murdered person appears to some close relative or friend of his, and enjoins him to take revenge. b) Revenge is conceived as a sacred duty and not as a kind of wild justice. The avenger is moved by a sense of sacred duty", and not out of any passion, say greed, or hatred for some personal injury. c) There is a piling up of crude, physical horror upon horror's head, and thus there is much that is sensational and melodramatic. These terrors are intensified by the repeated appearance of the ghost. d) In the end, there are a number of deaths and the stage is left littered with dead bodies. e) There is abundant use of the imagery of violence and terror. f) Prominent role is assigned to some rascally servant known as the malcontent, a Machiavellian-villain much given to reflection and satiric comments. g) Sympathy is aroused for the avenger" (www.Brain.net).

\section{DISCUSSION}

\section{Thomas Kyd's Spanish Tragedy}

The credit for popularizing the revenge tragedy in England must go to Thomas Kyd, who was one of the university wits of the Elizabethan period. He was interested in the tragedies of the Greek dramatist Seneca very much and they were his favorite reading. When reading his plays, one can see that the chief characteristics of the Senecan tragedy re-appear in his masterpiece, The Spanish Tragedy. The immense popularity of this play is accounted for by the fact that the people wanted romantic melodrama and Kyd gave them what they wanted.

Spanish Tragedy is the first really effective tragedy in the Senecan style. The atmosphere is one of terror and gloom and the terror is produced by the piling up of crime, often monstrous crime. There is also heaping up of murder. A young prince is killed treacherously at the very moment he is to marry his beloved. His father feigns madness and plans revenge. He succeeds too well and in the end everyone including himself is killed. The stage is littered with dead bodies. The ghost in the Senecan manner appears at intervals throughout the tragedy to demand revenge. There are also long, declamatory speeches in the Senecan style.

Despite this classical influence, the tragedy does not actually follow the norms and classical rules of dramatic writing. There is no unity of time and place, but there is unity of action and unity of motif, for it all centers round revenge. There is also much action on the stage, while there is no such action in the Senecan tragedy.

\section{Shakespeare's Hamlet}

William Shakespeare, perhaps the greatest of his contemporaries, wrote Hamlet essentially as a revenge tragedy. This play has been raised to the level of high tragedy by the genius of the dramatist.

Hamlet's father is murdered by his uncle; the ghost of the murdered king appears to his son hamlet and promotes him to take revenge for the wrongs done to him. The revenge "is enjoined upon him as a sacred duty" (Simon, 1984, p. 12). Hamlet is determined to perform this duty, but he hesitates and delays. The result is, some murders finally happen and all the dead bodies are left on the stage. Revenge motif is the basis of this play, there is much in it that is crude, melodramatic and sensational.

However the various soliloquies of the prince give us a sign into his tortured soul. We also realize that he is an essentially noble soul and his masterly inaction results from his inherent nobility. It is in this way that a crude melodrama becomes a high tragedy, a play in which tragedy is a matter of character and not merely an external horrors.

\section{Marston's Antonio's Revenge and Antonio and Mellida}

Another great writer of revenge tragedies is John Marston. The best of his tragedies are Antonio's Revenge and Antonio and Mellida. Both of these tragedies are the direct descendants of the The Spanish Tragedy. These plays are written in the Senecan Tradition, and are characterized by coarseness, brutality and violence. They also reveal the cynicism and pessimism of the dramatist himself. They lack originality and are frankly imitative. When reading these plays, one can find greater coarseness in the playwright himself than in other writers.

\section{George Chapman The Revenge of Bussy D'Ambois}

Another great writer of revenge plays is George Chapman. His play, The Revenge of Bussy D'Ambois is a good and powerful play. In 1604 he had written the tragedy of Bussy D'Ambois, that it is about a brilliant swordsman at the court of Henry the Third of France, who was trapped by Count Monsturry for an intrigue with the connivance of the king's brother, the Duke of Guise.

Chapman followed it up about six years later with The Revenge of Bussy D'Ambois in which he deserted history altogether and even invented a brother of Bussyy's, whom he named Clermont, to avenge him.

On this figure Chapman concentrated all his powers. Clermont expressly called in the play 'This Senecal man', is the ideal Stoic. A grave moral teacher, studious of perfection in himself and others- this was the man on whom Chapman imposed the duty of taking swift, decisive, and ruthless action. Even without the clue that the author gives, we can see a certain kinship with Shakespeare's Brutus, and the relationship to Hamlet is nearer still. The Revenge of Bussy $D^{\prime}$ Ambois, is the only play by Chapman with a clearly defined debt to Shakespeare.

In the very opening of the next century, there were two dramatists who put new life and vitality into revenge tragedy. These two dramatists are Cyril Tourneur and John Webster. 


\section{Tourneur's The Revenger's Tragedy and The Atheist's Tragedy}

Tourneur's masterpieces are The Revenger's Tragedy and The Atheist's Tragedy. Both of the tragedies are set in Italy, in a coarse and brutal world of crime and vice, from which there is no escape and which knows no pity. The theme is revenge and punishment and the action moves swiftly, clearly and with intensity. They are revenge tragedies in the tradition of The Spanish tragedy, and in their flashes of dramatic power, the greatest of the later revenge plays. Simpson writes that "the savagery of the play is its most marked characteristic, a long-deferred vengeance carried through to the accompaniment of murder, rape and incest. As always in the world of decadence, there is a striving after originality. And in one point the author has succeeded better than one could hope; he has drawn with an unfaltering hand the temptation and the triumph of one pure woman" (qtd. in Carpson, 1996, p.45).

\section{John Webster's The Duchess of Malfi}

Webster's The Duchess of Malfi "has several features of a revenge tragedy. There is a free exploitation of crude, physical horrors, like the dance of the mad men, the presentation of a dead man's hand to the Duchess, the showing to her of the wax figures of her husband and children as if they were dead, the appearance of the tomb-maker and the executioner with all the apparatus of death. There are a number of murders including murders by strangling and poisoning. Imagery of violence, decay and corruption has been abundantly used "to intensify the atmosphere of horror" (www.Brain.net). There is also a Machiavellian Malcontent, the character of Bosola who is a rascal indulges in satiric reflections of life.

When The Duchess of Malfi is studied carefully, one can realize that the play differs in a number of ways from the traditional revenge play. For one thing, the revenge motif is weak in the play. It does not become clear why revenge is taken on the Duchess. Her only fault is that she married below her rank and status and thus, as the two brothers think, she has disgraced the family. She has certainly not committed any heinous crime and the horrible tortures to which she is subjected are unjustified, and far in excess of her guilt. That the revenge motif is weak is clearly brought out by the fact that for more than two years Ferdinand and the Cardinal do nothing to punish the Duchess. Ferdinand informed of her marriage as soon as her first baby is born, and she has two other children before Ferdinand acts to have his revenge. If at all there is a revenge motif, it appears late in the play when Bosala avenges himself on the cardinal and Ferdinand for their ingratitude to him, and also because he has been touched by the murder of the Duchess and decides to avenge it (www.Scribd.com).

Further, the issue of revenge in this work is not a sacred duty enjoyed by the supernatural as in the Senecan tragedy, but it can be "a satisfaction of a personal passions. Ferdinand's motif might be greed for the estate of the Duchess or sexual jealousy resulting from his incestuous passion for her, or it may merely result from the morbid pleasure which the brothers take in inflicting pain. In the case of Bosola, the motif is certainly the ingratitude of the two brothers. It is a satisfaction of personal grudge. No doubt, Webster has made free use of crude physical horrors, but these horrors are made an integral part of the tragedy. The sensational and the melodramatic is seen acting on the soul of the Duchess, and in this way her inner suffering, in grandeur, majesty and nobility of her soul, are fully revealed. In this way the melodramatic is raised to the level of pure tragedy. In this way the horrible is subordinated to the total artistic effect the artist wants to create. The horror in the play does not remain something extraneous as is the case with other writers of the revenge play (www.Scribd.com).

Intensity of moral vision is another contribution of Webster to the revenge tragedy. In this tragedy, revenge is made to look ugly and repulsive. In the end our sympathies are not with the avenger or avengers as in the conventional revenge tragedy, but with the victims of revenge.

We sympathies with the Duchess, we are conscious of her nobility, dignity and innocence, and our sense of justice is satisfied when the avengers perish. Our moral sense is gratified with the death of the Cardinal and Ferdinand, and revenge is felt to be something obnoxious and unethical.

Webster further transformed the revenge play by adding poetry to it. He was gifted with a poet's imagination and the poetry of his play has been admired by on critic after another. Schelling says that "the power of Webster, at his best is the revealing power of love, the poetry of sadness, the poetry of pathos, the poetry of ruin, and these poetic touches take off the edge of the various gruesome murders' (qtd in Philips, 1998.p.67). In Act IV of the play, Webster's poetry is all the more impressive because of its wistful, tender charm, wrung out of the very heart of tragedy. Webster's splendidly imaginative vision and his poetic insight relieve the gloom and tedium of the play.

\section{CONCLUSION}

Tragedies and revenge tragedies come from the stories of human beings all around the world. The first revenge tragedies such as The Spanish Tragedy that were produced during the Elizabethan period are historically important. The reason is that, such a play for example, foreshadows Shakespeare's Hamlet, in detail as well as in spirit. In this play we also get for the first time, the hesitative type of hero. Its tragic gloom is the gloom of a Shakespearean tragedy. However, Kyd lacked that vision and poetry which Shakespeare alone could supply.

The Spanish Tragedy is also important for it gave rise to the vogue of the revenge tragedy, a kind of tragedy which enjoyed immense popularity throughout the Elizabethan era. The revenge motif was exploited ad infinitum by Elizabethan and Jacobean dramatists, and all its possibilities were soon exhausted. The search for novelty resulted in ever increasing crudities and absurdities, and the revenge play died a natural death.

As the tragedy moves from the Elizabethan period towards the Jacobean era and the next century, the revenge tragedy degenerated into crude melodrama and there was a piling up of horror upon horror's head. Murder and bloodshed were introduced in abundance to provide thrills and sensations to the degenerate tastes of the theater goers. 
Dramatists still continued to exploit the revenge motif, but it soon ceased to occupy the central place, and was relegated to the background.

\section{REFERENCES}

Abrams, M. H. (1999). A Glossary of Literary Terms. Seventh Edition. Heinle and Heinle.

Barry, P. (2002). Beginning Theory: An Introduction to Literary and Cultural Theory, $2^{\text {nd }} \mathrm{Ed}$, Manchester: Manchester University Press.

Carpson, D. (1996). Drama and Performance. London.

Kirkpatrik, D.L., ed. (1988). Contemporary Dramatists. $4^{\text {th }}$ ed. New York: St. Martin's Press.
Philips, J. (1998). Tragedy and its Effect in the world of Literature. London.

Simon, J. (1984, Jan 16). All Done with Mirrors. New York Magazine, 64-65.

Widdowson, P. (2004). The Palgrave guide to English Literature and its contexts 1500-2000. Palgrave Mac Millan. NY.

Wilkinson, K. (2010). The Performance History. In Lisa Hopkins, 'Tis Pity She's a Whore: A Critical Guide. London: Continuum International Publishing Group.

http://www.scribd.com/doc/21423701/Duchess-of-Malfi-asa-Revenge-Tragedy

http://www.brain.net.pk/ chfayyaz/books/E 